\title{
PASSIONARITY OF PRESCHOOLERS AS INDICATOR OF THEIR LIFE ENERGY
}

\section{Havrysh Nataliya ${ }^{1}$ \\ Krytiy Katerina ${ }^{2}$}

DOI: http://dx.doi.org/10.30525/978-9934-571-27-5_10

\begin{abstract}
According to psychologists and educationalists, the reason for many problems in personality development of modern children is their passivity and unwillingness to take the lead and to assume the role of the leader. Growth of personality passivity is expressed in various forms of their behavior, which indicates the depth of penetration of passivity into the structure of the child's personality. The lack of activity in self-consciousness, communication and different forms of activities deforms the process of socialization of the preschooler's personality, which manifests itself in contact avoidance, problems with interaction, solitude- proneness. All this shows the acuteness of the problem of personality passivity and the relevance of theoretical and technological research of the formation of passionarity in preschool children.
\end{abstract}

The study of social-psychological nature of personality passivity, determination of the factors influencing the development of passionary qualities of preschool children was the purpose of our study. The subject of the research was peculiarities of the development of passionary qualities and their influence on preschool children's speech. On the basis of the systematic theoretical analysis of passionarity as a scientific phenomenon from the standpoint of philosophy, psychology and pedagogy, the polysemantic and diverse content of the key term of the passionary theory of ethnogenesis has been proved; the definition of passionarity as an integrative characteristic of a personality, whose qualities are directed towards self-improvement and the improvement of society, are based on the activity of the personality and have social significance.

\footnotetext{
${ }^{1}$ Doctor of Pedagogical Sciences,

Professor of the Department of Psychology and Pedagogy of Preschool Education,

Pereyaslav-Khmelnytsky State Pedagogical University named after Gregory Skovoroda, Ukraine

${ }^{2}$ Doctor of Pedagogical Sciences,

Professor of the Department of Pedagogy and Primary and Preschool Education,

Ternopil National Pedagogical University, Ukraine
} 


\section{Passionarity of preschoolers as indicator of their life energy}

These include: purposefulness, ability to overcome obstacles and to cope with overstrain, complementarity, leadership, adaptability, developed intuition, constructive aggressiveness and mature emotionality. On the basis of the analysis of psychological and pedagogical research there were determined the factors of influence and peculiarities of the passionarity manifestation as the ability of a personality to change the environment and themselves, the need to overcome difficulties, which is already manifested in the stage of preschool childhood. In order to study levels of passionarity manifestation, diagnostic tools have been developed to identify predisposition of preschoolers to passionarity on the basis of content analysis of their speech. The analysis of children's speech helps to analyze their predisposition to manifest passionarity and to define the type of personality: passionary (over-energetic), persistent (moderately energetic), subpassionary (energy-deficient). In the first stage of the diagnostics we used the analysis of game activities. In the second stage of the diagnosics there was the analysis of child's speech, in which passionarity was determined through existence in their speech a greater number of words peculiar to a passionary personality.

Among the priority ways of solving the problem, scientists name such directions as the pedagogy of fun and the pedagogy of experience, which are focused on the life experience of interaction and cooperation with other people; the experience of communication with nature, that is, a person must learn to live in a diverse world, and obtaining of their experience should be voluntary. Thus, it has been proved that passionarity is a dynamic feature of the psyche that occurs as a result of passionarity push, and forms a certain number of people, within the population, who tend to act. Development of activity as internal energy is possible on condition that there is imagination, creativity and courage, self-confidence, self-reliance, purposefulness and ability to prove own opinions.

\section{Introduction}

Preschool age is crucial in the formation of cognitive features of the character. In childhood children are the most active: they are lively and inquisitive. Mental qualities of the personality formed at this age turn out to be persistent and are preserved in their main features (taking into account age characteristics and new formations) for many years (O.M. Podd'yakov) [13].

According to psychologists and educationalists, the reason for many problems in personality development of modern children is their passivity 
and unwillingness to take the lead and to assume the role of the leader. The lack of activity in self-consciousness, communication and different forms of activities deforms the process of socialization of the preschooler's personality, which manifests itself in contact avoidance, problems with interaction, solitude-proneness (I.S. Zimina).

Passivity of a personality reveals itself most vividly at the senior preschool age due to the low level of interconnection of emotional and verbal reactions. Any activity, despite the kind of children's performance, makes such preschoolers feel alarmed since they have to show their worth and have to be noticed, which they do not like very much. As a result, if it is possible, they will avoid that. Very often the cause of such passivity is a negative experience - taunting, reproach, and even mocking at the child for the manifestation of unwilling activity, from the point of view of an adult (or peers). The passive state of the child is being shaped at exactly the time when they think that they will not be able to perform the task by themselves.

Although the phenomenon of a preschool-child's passivity as an integral behavioral act that affects development, formation and socialization of a personality has been studied insufficiently in psychology, the determined signs of manifestation of personality passivity in the stage of preschool childhood make it possible to assert that. Passive preschoolers have weakly developed volitional processes; they prefer to be unnoticed, follow someone, obey and be diligent lest they should not be disturbed. Growth of personality passivity is expressed in various forms of behavior: shyness, timidity, fear, insularity, aloofness, which first originate as an emotional reaction, or as a psychological defense, and later become a stereotypical behavior strategy. These forms of passive behavior point at the depth of penetration of passivity into the structure of the child's personality.

The problem of passionarity under the conditions of decreasing of personality activity, even in the early stages of ontogenesis, has increasingly become the subject of scientific research recently. From a psychological standpoint, this problem is studied by: V.Y. Bogdanov, who made a comparative analysis between the personal typology of L.M. Gumilyov and the psychological typology of character accentuation by K. Leongard; M.I. Kovalenko (he studied interrelation between passionarity, temperament and personality motivation) [12]; K.G. Frumkin, who tries to explain passionarity through the theory of sexuality by S. Freud (passionarity as manifestation of sublimated unconscious drives) etc. [17]. 
The purpose of the study is to identify peculiarities of the development of passionary qualities and their influence on preschool children's speech.

The object of the study: passionary children of the senior preschool age.

The methods of the study in this stage of work: analysis of theoretical sources of the problem under study; diagnostics; objective observation.

\section{Terminological field of the problem of passionarity}

Analyzing common models of a child-parent interaction, scientists determine certain factors that negatively affect the support of activity as the basic quality of the personality. Among them there are: computer addiction at an early age, weakening of the organism (frequent diseases), long lasting passive state and even children's depressions. Unfortunately, a significant number of children are inclined to passivity in their early childhood. Parents and educationalists more and more often notice such children's manifestations as insularity, apathy and laziness.

Scientists assert that passive behavior stereotype at the senior preschool age can be overcome due to a special system of pedagogical influence [19;21]. According to them, in modern economic surrounding, passionarity which is an integral part of personality competitiveness is to be developed as a competence, beginning from the preschool age. But before outlining technological aspects of the problem, let us turn to the theory of passionarity.

Modern Ukrainian society, as well as other countries, needs to increase the number of passionary personalities for its development and improvement. The author of the theory of ethnogenesis L.M. Gumilyov in the context of the passionary theory of ethnogenesis in 1939 predicted passionary pushes that can occur once in one thousand five hundred years and correspond to the period of society development, when the ethnic group becomes extinct, regresses and dies [6].

Thanks to L.M. Gumilyov, who defined passionarity as a characteristic of a person or an ethnic group, the term passionarity firmly entered the scientific field and the everyday life of society. The author gives some of his own definitions of passionarity and passionary personality. The most important definition for our study is the one according to which passionarity means a set of personality qualities that provide an active life position of the person: "Passionarity is a characterological dominant, an irresistible inner desire (drive) (conscious or, more often, unconscious) of activities aimed at achieving a certain aim (often illusory). It should be mentioned 
that this goal is sometimes considered by a passionary personality even more valuable than their own lives, and even more valuable than the life and happiness of contemporaries and tribesmen" [4, p. 33]. Thus, the above definition characterizes personality as ambitious, strong-willed and active.

Passionarity (in a broad sense), according to scientists, is an integrative characteristic of the personality whose qualities are directed towards selfimprovement and improvement of society and are based on the personality activity and have social significance: purposefulness, ability to overcome obstacles and ability to cope with overstrain; complementarity, leadership, adaptability, developed intuition, constructive aggressiveness and mature emotionality [5].

However, it is quite natural that over time the meaning of the concept of passionarity has transformed and now its meaning differs from the one that was implied by L. M. Gumilyov [3].

Thus, Y. Beglov, the author of the information theory of thinking, proposes to determine passionarity from the standpoint of person's conscious understanding of their actions. "Passionarity is a predisposition to choose behaviors with poorly predicted effects instead of the well-predicted ones but with unsatisfactory after-effects. Such predisposition is the property of the current state of thinking which can be caused by innate features of the brain, evoked by behavior stereotypes and personal experience" [1].

A broad definition of this term is given by modern dictionaries of foreign words, namely: passionary (from the Latin passio - suffering and even passivity, but also affect, passion; the one who possesses a higher activity, passion, whereas a passionarian (passion-filled) is an active person who has considerable inner energy. Derivatives in European languages differ in connotation. The British added a new meaning to passionarity: for them passion is an outbreak of anger; for the Poles it is rage, fury; passionant in Romanian is a person capable of carrying along and exciting others; for the Dutch, Danes, Germans and Swedes passion is just an excitement; in Ukrainian, the Latin passio is interpreted as passion (npucmpacmb). In everyday wide use, they call it any strong desire and even a weak drive. Thus, the etymology of this term, which is so polysemantic and diverse, is being specified. When appeared, this concept triggered various reactions in the scientific world: from admiration to hard criticism.

It should be noted that even today the interpretation of the term has different variants depending on the authors' scientific preferences. For exam- 
ple, D.G. Davydov in his studies equates the concept of passionarity with the notion of vigorousness, proposed by M.P. Karpenko (from the English vigorous - active, cheerful, full of energy) [7].

Let us summarize: the study of passionarity reveals the polisemantic and diverse content of this key term of the passionary theory of ethnogenesis. As a working one, we will use the definition of passionarity as the ability of a personality to change the environment and themslves, the need to overcome difficulties. The important thing is that passionarians characterized by dominating needs of self-actualization, and subpassionaries - by the predominance of vital needs. A passionarian can have an extraordinary I-concept from the point of view of society and see their potential and its implementation (i.e. self-actualization) in a special way.

The outstanding violinist of the present time M. Kazynyk, being himself a passionary personality, gives examples of Alexander the Great and Johann Sebastian Bach. M. Kazynyk claims that they should be considered as passionary personalities because they made an invaluable contribution to the formation of the European civilization culture, but in fact one of them was a commander who conquered and sent to death thousands of people, and the other served as an organist and chorus master during all his life [11]. Passionarians who are active creators of history make up a small part of society $-3-5 \%$ [10, p. 59].

M. Kovalenko [12], the author of the psychological theory of passionarity, also draws analogy between passionarity and adaptability. In his opinion, passionarity - harmony - subpassionarity can be correlated by the scale of adaptability; therefore, there will be a sequence: over-adaptation - adaptation - disadaptation. Y. Biglov believes that mental processes of passionary personality can be developed from early childhood [1].

\section{Psychological and pedagogical influence on active children or where and how passionarians disappear}

The presented analysis of scientific approaches to the problem of passionarity will be continued in the vector of psychological and pedagogical research. What is pedagogical potential in raising a passionary personality? What kind of personality can be called a passionary one from a pedagogical point of view? And can a psychological and pedagogical impact be that passionarity push in the development of children to help them maintain their leadership qualities in preschool age? It is these issues that ought to be considered in more detail. 
First of all, let us recall how often teachers make the following entry in their plans for educational work with children: "To raise discipline in children". In reply to the question What is discipline?, the best answer that can be received may be: "sit still, listen to the teacher, be quiet". From ancient times, the word disciplina (from the Latin - education, upbringing, school) was used in the sense of punishing slaves with a scourge, a whip, a knife or a stick. There were even various types of punishment - disciplina sursum the upper punishment that is scourging of shoulders, back, chest, and also disciplina seorsum - the lower punishment, scourging of what is below the back. Nowadays, the term discipline is used very widely, sometimes even too much. That is why teachers should first of all determine for themselves what discipline is and how discipline is raised in a child of preschool age. The prominent Ukrainian educationalist Sofia Rusova warned adults against misusing of discipline methods: "A teacher should never confront with his /her pupil, but must find noble directions where to turn the rest of the forces that appear in this instinct lest it should not turn into a major violence and mischief [15, p. 42].

Thus, S. Rusova writes about the instinct of the struggle, using the term to confront in the sense to take up a struggle with someone or something. And then the author emphasizes: "Children are born with natural inclinations to activity" [16, p. 140], "a child is an assimilating-through-activity, creative individual [16, p. 60]. Rereading S. Rusova's works which are still of current importance, we find an interesting expression militant inclination. This is how the educationalist explains her point of view: "We must not oppress the militant inclination, but we must vector it in accordance with the needs of our present state of development ..." [16, p. 16], "the whole life is a struggle - our children must be prepared for this struggle, and the process of upbringing must make children strong and courageous, and the main thing - the process of upbringing must outline the goals for which they must struggle [16, p. 17]. And finally, as a statement: “... we have no right to put out the militant instinct in our children, but we must bring and direct this vibrant, vital instinct towards a good purpose, we must teach our children to direct it to improvement of the well-being of our society, to the cultural and economic development of our people, our region" [16, p. 18].

However, ignoring the known theoretical statements in practice turns fatal. Obviously, most of us are familiar with Petryk P'yatochkin, a literary character created by the writer and scriptwriter Natalia Guseieva, or with 


\section{Passionarity of preschoolers as indicator of their life energy}

the character of the famous animated cartoon How Petryk P'yatochokin Counted Elephants (Kyivnaukfilm, 1985, directed by Alexander Viken). Let us remember, Petryk comes out of his house in Obolon in Kiev, cheerfully dispersing the pigeons. He is followed by his parents who give him the last instructions, but he does not listen to them. This is a lively and energetic child living in a joyous and infallible child's world. Yes, this boy is disobedient, but which of us was obedient at his age? He jumps onto the skateboard, spoils the neighbor's clothes and breaks loose from his father's grip, with a car missing him by inches.

Petryk is taken to the kindergarten, but his whole body resists - he wants to delay the meeting with the System. He would rather do damage and run a risk than endure this boring young preschool teacher all day long [2]. Having taken the child to the kindergarten, the parents breathed a sigh of relief, but there began a headache for the pre-school teacher. Because with Petryk's arrival, the quiet children stopped behaving themselves as if someone had replaced them. There came the leader whom they followed and repeated everything after him. The children consider Petryk to be their leader and repeat all the tricks after him. For the pre-school teacher, even such a simple task as counting the children becomes almost impracticable [2].

Petryk realizes his otherness, not wanting to be a screw, an element of the system. He is devoid of social conformism. No wonder when the teacher calls to order ("There's a buzz where you are! It's time you came to your senses!"), he hints that he has his own way, dao, which is beyond him: "I have tied my legs hard, to forget about the road ...". An interesting and controversial point of vew is A. Bonndar's one about a new method of influence which is much more delicate than all the available methods of influence [2]. The teacher supposedly plunges Petryk into a hypnotic state that goes into a dream. In this dream, using the method of projection of the elephant's behavior on the child's one, the value orientations of the child change completely. A completely innocent technique - to count the elephants before the day's sleep - changes Petryk's personality completely. "Somewhere in far Africa, near the river Limpacheky" - the teacher uses magic spell. She calls out the image of an elephant, designed to convey morality to Petryk's consciousness: he mustn't behave like he does. And the boy wakes up changed - he becomes passive, disorientated and chilled. There is the impression that somebody has picked thoroughly in his brain. 
So, in an unobtrusive way, with the help of suggestion, the anarchist-passionarian, who is respected by all the children, has been transformed into the man of the system, the screw. According to A. Bondar, the teacher turned to be much more efficient than nurse Ratched from the novel by Ken Kesey One Flew Over the Cuckoo's Nest [2]. No, this is not an electroshock and not a lobotomy that turned McMurphy into a plant, but something much more effective. From now on, when once she says, "Let's line up, children ...", the normalization program works flawlessly. The pre-school teacher in the cartoon has no name. She is a normalization machine, a person of function. The social group leader is adjusted to meet the requirements of the system, which will not fail at the micro and macro levels. In such a way Petryk's spring, which allowed him to walk topsy-turvy, not to be the same as everyone, breaks. His personality is broken off by a straight pin of the Soviet discipline. And this is the purpose of the educational institution - to break the spring, the resistance of an individual, to straighten the convolutions and break severely. This is the moral of that great cartoon: nobody will go out of there being their own selves [2]. The children take one another by hand and, like the rats following Nils, follow the teacher.

The System has won. So, Petryk P'yatochkin, according to modern surveys, is undisciplined, hyperactive, is in a continuous motion, "this boy, like a fluffy bunny, has a hidden, extremely jumping spring." It is exactly due to this excessive vitality Petryk creates constant problems around him: he knocks the neighbor's bucket; his parents must constantly control him so that he shouldn't run away; he turns everything upside down in the kindergarten and cannot be controlled and lead. The cartoon shows what can help Petryk - a wise pedagogical approach based on love, patience and understanding. However, unfortunately, in life changes do not come as fast as in the cartoon, and are a consequence of long, consistent education.

In the cartoon, Petryk P'yatochkin is a positive character and wins everybody's sympathy; he is sincere, ingenuous, friendly and energetic. However, in his behavior there are also a lot of things that cause a negative reaction of others: rejection, condemnation and misunderstanding. That is why the full development of such children, their further self-realization and the preservation of leadership qualities are at threat; the pressure adults make on an active child can be very strong.

Passionarity (life energy) of such children impedes teachers, so, they make a lot of effort to extinguish activity, sometimes using methods of 


\section{Passionarity of preschoolers as indicator of their life energy}

physical coercion: they make the child sit still or stand in the corner, they lock this child in the bedroom, etc. Another example, but of subpassionarity, may be the behavior of the Hedgehog in the cartoon Hedgehog In the Fog by Yuriy Norstein. The depicted friendship of the characters does not imply the pursuit of a common goal, common overcoming of difficulties, and even the organization of a game, which requires at least minimal tension of mental and physical forces. Every night the communication between the Hedgehog and the Bear is focused on counting the stars on the both sides of the chimney- an absolutely meaningless thing which is not energy consuming. The statement of the situation by the Hedgehog: "I'm wet through. I will soon sink", is pronounced in such an indifferent tone as if there were not a threat to its own existence. This is a typical behavior of a subpassionarian, whose energy, according to Gumiliov, is not enough even to support the instinct of self-preservation which is peculiar to every living being. So, in what way is passionarity formed?

Created by L.M. Gumilyov Passionary Theory of Ethnogenesis [3] suggests three ways: micromutations due to the factors of inanimate nature; genetic transmission (heredity); passionary induction.

The assumption that passionarity is inherited has not been scientifically proven, but the fact that it is contagious is known and proven. Thus, ordinary citizens who are in proximity to any epicenter begin to behave as passionary ones. If a person goes away for a certain distance, they behave again as usual. This phenomenon is called passionary induction and is actively used by experts. Obviously, the first two ways have nothing to do with upbringing. Passionary induction will be understood as changes in the mood and behavior of people in the presence of more passionary individuals.

Thus, passionary induction can be described by a powerful word combination proposed by Gumilyov himself: passionarity is contagious. One of the factors that affects the reduction of the child's vital activity is the expressed or unexpressed passionarity of the teacher. If he or she has actualized passionarity, they will invest a significant amount of energy in the realization of their pedagogical idea, in the vector of their own activity (according to Gumilyov, passionarity is a vector magnitude), will correspond to the vector of pedagogical purpose. By inducing pupils, the passionary teacher will provide actualizing of their passionary potential, directing the vector of child's passionarity into solving their pedagogical tasks. Consequently, such a property of passionary personality as passionary induction can be recognized as the key one. 
The authors of the article Lay Epistemic Theory: The Motivational, Cognitive and Social Aspects of Knowledge Formation (2010) Arie W. Kruglanski, Edward Orehek, Mark Dechesne and Antonio Pierro prove that one of the results of passionary induction in education is strengthening of teacher's epistemic authority. Epistemic authority is the degree of trust experienced by a person (in our case, a preschooler) in relation to the subject as a carrier and translator of knowledge, as well as sources of information [19]. In other words, the higher the epistemic authority of the teacher is, the more likely it is that children will take the information given to them as reliable knowledge, believe in teacher's words, trust their knowledge. Therefore, you can often hear from a child, who is educated in a kindergarten by a teacher-passionarian, that "... Oksana Tarasivna said ...", which means that all that must be done only this very way. Summarizing the above thesis, we can draw a clear parallel with the process of passionary induction: passionary teacher makes children believe in their own strength, often creates situations of success and pedagogically justified situations of failure (O. M. Podd'yakov) [13].

Understanding the mechanism of epistemic authority formation and the mechanism of passionary induction, it can be noted that passionary induction contributes to strengthening of the epistemic authority of the preschool teacher.

Very often, on adults' initiative such Petryks P'yatochkin go to see the doctor - either a neuropathologist or a psychologist. Vitality, interest in the environment, activity in movements is a ready diagnosis of ADHD - attention deficit hyperactivity disorder. After careful consideration of the diagnostics indicators used to give this diagnosis, one may feel terrified.

It turns out that an active child with rather vital innate energy is almost ill. This child can be diagnosed only by some signs noticed by the psychologist or neuropathologist. So, psychologists are proposed to define ADHD, if the child: spins while sitting on a chair, often rises from his/her seat in class during lessons or in other situations where they are supposed to stay in their seats; shows idle motor activity: runs, spins, trying to climb somewhere especially in situations when it is unacceptable; usually cannot play quietly or do something in spare time; is often in constant motion and behaves as if "a motor were attached"; is often talkative; often answers questions without thinking, without listening to the question up to the end; usually cannot wait for their turn in different situations; often interferes with others, 


\section{Passionarity of preschoolers as indicator of their life energy}

bothers others (for example, intrudes conversations or games); is constantly moving, crumpling the sheet and dropping off the blanket on the floor while sleeping. We hope that adults have enough professional and worldly wisdom to admit: these features are typical of almost every physically healthy, developed and active child. These diagnostic tools cannot be relied on and $A D H D$ cannot be diagnosed with their help.

\section{Interpretation of the diagnostics results and ways of preserving preschool children's passionarity}

We propose diagnostic tools for defining preschool child's predisposition to passionarity on the basis of their speech content analysis. The analysis of children's speech helps to analyze their predisposition to manifest passionarity and to define the type of passionary personality: passionary (too energetic), persistent (moderately energetic) and subpassionary (energy-deficient). Persistence means stability, low variability, endurance of the personality. Persistent individuals are less prone to asocial manifestations.

According to I.S. Zimina, they tend to keep away from public life, have little initiative, they are conservative, but can be good performers [9]. In our research, the term persistence is used in the sense of constancy.

Playful activities of children in a group (up to 7 people) were under observation during one hour. The researcher recorded in the observations diary all the expressions of one child chosen for the observation. Children's statements, typical each category, helped to determine child's predisposition to passionarity. The first stage of the diagnostics is the analysis of gaming activities. During the game passionary children (too energetic) demonstrate: high activity, frequent change of posture, gesticulation, loud voice, use of facial expressions; bright emotions that show passion, optimism; prevalence of passionary words in their speech (mainly verbs of motion, direction and the pronoun $I$ ). Persistent (moderately energetic) children show: moderate activity, the ability to stay in one position for a long time and play alone, monotony of the game, balanced intonations in speech, limited facial expressions, gesticulation; emotional restraint, increasing of emotional tone in personally significant situations, shyness; the prevalence of persistent words (mostly nouns and verbs of moderate activity; use of the pronoun $W e$ ). Subpassionary ones(energy-deficient) are fussy, sedentary, inactive; they play only in the group on the initiative of other children; barely heard weak voice, poor gesticulation and facial expressions; infantile emotions 
(pleasure as joy and discontent as crying), indifference, apathy, expression of anxiety, pessimism; prevalence of subpassionary words (mostly nouns with adjectives or derivatives from adjectives in the form of adverbs it is boring, it is uninteresting, etc., use of the pronoun They) [9].

The second stage of the diagnostics was the child's speech analysis. First of all, the unstimulated speech of the senior preschool children was studied, namely: the state of speech development of each child was studied. The main criterion of assessing speech development was getting into contact with the child. It was taken into account that each child has their own special, unique way of speech development, which may not coincide with the speech development of other children.

The assessment of the child's speech development state included: collecting of information (monitoring the child's speech, analysis of the responses and results of child's activities, talking with parents, etc.); recording of the received data; interpretation of the results. The analysis of the speech of senior preschool children gave reasons to identify such components as category of children and parts of speech. In the speech of passionary children, the prevalence of such nouns, verbs, adjectives, pronouns was noticed: a battle, fun, a hero, foolishness, love, a victory, help, a messenger, joy, a word, a deed, a blow, luck, tricks; to find, to gather, to call, to convince, to defeat, to invent, to coerce, to humiliate, to assimilate, to suffer; active, fighting, volitional, business, exciting, passionate, interesting, red; I. Persistent children used: parents, home, help, friends, health, work, a family, patience; to play, to walk, to defend, to try, to unite, to ask, to learn; green, brown, reliable, hardworking, blue, calm, caring; We. The speech of subpassionary preschoolers was full of the following words: rest, a holiday, tiredness, food, laziness, a break, forgiveness, donation, rest, crying, sleep, fear; to fear, to turn away, to rest, to lie, to go, to sleep, to hide, to wait; dirty, boring, gloomy, gray, anxious, sick, dull, black; They.

Consequently, passionarity is diagnosed by determining frequent occurrence in the speech of a greater number of words corresponding to a passionary personality. There were recorded words, often used by such children, that can be defined as refined ones and which are seldom used even in adults' speech: to consider (instead of thinking over), to tower above (to stand over something), to thrash (to beat hard), to drag (to walk slowly), to strike up friendship (to make friends), to be saved from; (to get rid of someone), fidgety, jovial, ubiquitous, marvelous sight (unusual sight), etc. 


\section{Passionarity of preschoolers as indicator of their life energy}

Special attention should be paid to preschoolers, who besides being subpassionary, have speech disorders.

By speech passivity of the child it is understood the lower level of speech activity, conditioned by the peculiarities of speech development in ontogenesis, which manifests itself in insufficient formation of speech skills or in negative attitude to speech activity, in particular, or in the use of alternative ways while doing speech exercises, tasks, etc. We distinguish the notion of speech passivity and speech negativism. Speech negativism is, above all, persistent refuse of the child from communication, which is not always observed even in children suffering from logopathy. Such children require attention both from preschool teachers and from psychologists. Preschoolers' speech passivity, as well as refusal to communicate, is an indicator of lower activity. As for the analysis of the activities, it should be noted that subpassionary children most often perform proposed action immediately and incorrectly, but after adult's pointing to their mistake (required external control), evaluating and controlling actions begin to form, but there is already conscious self-control.

It has been proved that preschool children's self-assessment is different in different kinds of activities: in drawing, children assess themselves adequately; in literacy they overestimate; in singing they underestimate. It is known that children who distinguish their $I$ through activities overestimate themselves; children who distinguish their $I$ through the sphere of relationships lower their self- assessment; children with different status, position in the reference group, estimate themselves differently, unpopular children, as a rule, overestimate themselves. Consequently, the adult should help the child: to understand his/her peculiarities not only in activities, but also in behavior, relationships with people around; to form an adequate self- assessment. The author's experience in working with preschool children proves that control is most often the weakest point in regulation of the child's speech. Evaluation and control activities are primarily conditioned by children's ability to assess and control not only the actions of peers, but also to control their own activities. Evaluation and control activities perform a dual function, namely: they are necessary as a condition and a means of acquiring knowledge, skills and abilities formation, and at the same time, they are the most important condition for the use of acquired speech knowledge, developed abilities and skills.

Persistent preschoolers can correctly perform an action offered by adults and correct mistakes by themselves. They have selective self-con- 
trol, formed self-assessment - the ability to explain the mistake adequately and reasonably. Passionary children are quick to correct mistakes by themselves while performing a certain action. Evaluation and control actions are formed; there is unconscious self-control and self- assessment. How to preserve the germ of a leader in the child and the personality qualities necessary for the development of passionarity? Passionary children are active, cheerful and happily get to know the environment. Everything is interesting to them. Passionarity of preschoolers is also characterized by a high level of physical activity. They are energetic, curious, lively and emotional. In our opinion, playful activity (in all its forms and manifestations) will allow to realize the leadership qualities of the child.

A promising direction of work is introduction of the pedagogy of fun, which is successfully developing in the EU countries and is becoming widespread in educational institutions of Ukraine. Its peculiarity is the use of numerous means of self-expression. Children fulfill their desire for activity in playful and plotline dances, movements, music, accompanied by accentuating the teacher's attention on the children's achievements [8, p. 205].

Another priority in applying pedagogical efforts is experimentation. No wonder that psychologists offer to predict the future working activities of adults judging the playful activity of children. In our opinion, cognitive-research activities (educational situations, travelling) also allow to expand children's practical knowledge in experimentation, to specify it, to get some experience in child's interacting with the environment. Thus, playing and experimenting are bases for active passionarity of preschoolers and for leadership skills development, which is necessary to be preserved and developed in future.

In modern education, the so-called pedagogy of experience, or experimental learning is used (Erlebnispädagogik). Its founder is considered to be the German educationalist and public figure Kurt Hahn (1886-1974) [20]. The central notion of the pedagogy of experience is an experience. Experience is what a person undergoes themselves, it is individual and does not depend on the influences of others. This is a subjective, personal event in human's life.

At the same time, experience is the luggage of a person that he/she receives from reality. The task of the teacher is to introduce the child to the environment, to give him/her the opportunity to meet unfamiliar, unknown things, but what sense and colouring this experience will get in the child's 


\section{Passionarity of preschoolers as indicator of their life energy}

inner world depends only on children themselves. This is a private sphere, which the teacher has no right to intrude. V. Heckmair and W. Michl gave the following definition of the pedagogy of experience: "This action is an orientated approach where young people face physical, psychological and social problems that contribute to the development of their personality and provide the opportunity of bearing responsibility for the decisions made" [20]. They also formulated the basic principles of this pedagogy: a person must do everything by themselves, obtaining first-hand, direct experience; problematic situations must be real, not artificial (if it is cooking dinner, then it must be from real products, on this stove, making fire - in the woods, rocks - in the mountains); a person must get his experience of interaction both with nature and with society. To achieve the result, a person must learn to co-work with other people; the experience of interacting with nature should be both unusual (extreme, exotic) and ordinary, that is, a person must learn to live in a diverse world; getting experience should be voluntary. A person determines whether he/she wants to get one or another experience or not; whether to take risks or not; theyshould have the right to choose.

\section{Conclusions}

Passionarity is a dynamic attribute of the psyche. Passionarity is a feature that occurs as a result of passionary push (sharp changes in the stereotype of behavior caused by mass mutations) and forms within the population a certain number of people who tend to act (passionarians). Passionarians are characterized by high general mental activity and emotionality. Developing of passionarity should start at an early age: it is necessary to give a child the opportunity of trying himself/herself in different spheres - to be a singer, an actor, a dancer, a musician, a scientist or an inventor, but to notice what the child likes most, what he/she turns out to be good at, what gives the greatest pleasure, what he/she can do on their own. Without imagination, creativity and courage, self-confidence, self-reliance, purposefulness, ability to prove own opinions there will never be genuine discoveries, significant internal energy-activity will never develop.

Discoveries begin with intuition, and intuition begins from childhood at the lessons of different kinds, namely: children learn to compare not only quantities but also qualities; come up with hypotheses and invent experiments to verify their correctness; build first skyscrapers, using trial-and-er- 
ror method they learn to provide strength and stability of the construction; learn to decor their works, stopping in time and following the sense of measure; invent interesting techniques of connecting elements and interesting names to geometric shapes, vivid comparisons with objects around, etc.

Thus, the main task of an adult is to preserve child's natural activity and direct it towards good deeds. Agreeing with I.S. Zimina [10, p. 75], we define the passionary personality (from the pedagogical point of view) as a personality possessing a set of characteristics which have an energy basis: passion in all personal manifestations (emotional passion, intellectual passion, activity passion), purposefulness (conscious or unconscious desire to achieve the goal; personality that trusts intuition and is capable of emotional, intellectual and physical over tension and strain. We assume that passionarity is not only a biological phenomenon, but also a social-pedagogical one, therefore, passionarity of a preschool child can and must be developed, and to do that it is necessary to create special environment, taking into account child's individual potential.

It is essential to further the development of passionary qualities in preschool children, identifying ways and methods of support that will help achieve significant positive dynamics, as well as to reveal the potential of each preschool child, will direct their energy of into activities, useful both for the society and for themselves, that is, into socially meaningful activity during all the periods of childhood.

Thus, it is urgent to cherish, nurture and preserve each child's personal activity, which is expressed not only through manifestation of physical activity, but is also represented by various positive passionary qualities of a growing personality.

\section{References:}

1. Byhlov Yu. Sh. Passyonarnost', L. N. Humylev i popytka dyaloha s "Humylevtsamy" / Yu. Sh. Byhlov [Elektronniy resurs]. - Rezhym dostupa: http://bezbozhnik.narod.ru/gumilevitsa.htm

2. Bondar A. Yak Petryka Pyatochkyna zlamala systema. - Krayina // 2010. \# 6 (9). - S. 38-40.

3. Humylev L. N. Etnohenez y byosfera Zemly [Tekst] / L.N. Humylev. - M : Ayrys-press, 2011. - $560 \mathrm{~s}$.

4. Humylev L.N. Heohrafyya etnosa v ystorycheskyy peryod [Tekst] / L.N. Humylev. - L. : Nauka, 1990. -279 s.

5. Humylev L.N. Etnosfera: ystoryya lyudey y ystoryya pryrody [Tekst] / L.N. Humylev. - SPb. : Krystall, 2002. - 578 s. 

$415 \mathrm{~s}$

6. Humylev L.N. Konets y vnov' nachalo / L.N. Humylev. - M.: AST, 2008. -

7. Davydov D.H. Vyhorosnost' kak sotsyal'naya aktyvnost' v obrazovatel'nom prostranstve / D. H. Davydov // Chelovek v sovremennom obrazovatel'nom prostranstve : materyalы Vseros. nauch. - prakt. konf. - M. : Yzd-vo S•HA, 2009. S. $62-70$.

8. Derkach-Padyasek T.I. Spetsyfika vykorystannya metodyky KLANZA u navchal'nomu protsesi / T. I. Derkach-Padyasek // Naukovi zapysky Natsional'noho universytetu "Ostroz'ka akademiya". - Seriya "Filolohichna". - 2014. - Vyp. 42. S. 204-208.

9. Zymyna Y. S. Dyahnostyka passyonarnosty lychnosty s tochky zrenyya psykhoanalyza /Y. S. Zymyna // Vestnyk psykhoanalyza. - 2010. - \# 1. - S. 23-27.

10. Zymyna Y.S. Pedahohycheskye vozmozhnosty vospytanyya passyonarnoy lychnosty // Pedahohycheskoe obrazovanye. - 2007 - \# 1. - S.59-75.

11. Kazynyk M.S. Taynы henyev /M. S. Kazynyk, M. : Leheyn, 2010. - 304 s.

12. Kovalenko M. Y. Passyonarnost' kak psykholohycheskyy fenomen / M. Y. Kovalenko // Psykholohycheskye problemy samorealyzatsyy lychnosty. SPb. : Yzd-vo SPb. un-ta, 1999. - S. 67.

13. Podd'yakov A.N. Yssledovatel'skoe povedenye: stratehyy, poznanyya, pomoshch', protyvodeystvye, konflykt / A. N. Podd'yakov. - M. : Erebus, 2006. $372 \mathrm{~s}$.

14. Rusova S. Doshkil'ne vykhovannya // S. Rusova. Vybrani pedahohichni tvory. - K. : Osvita, 1996. - S. 34-184.

15. Rusova S. Nova shkola sotsial'noho vykhovannya / Sofiya Rusova. Vybrani pedahohichni tvory : U 2 kn. - Kn. 2 / Za redaktsiyeyu Ye. I. Kovalenko; Uporyad., prym. Ye. I. Kovalenko, I. M. Pinchuk. - K. : Lybid', 1997. - S. 16-104.

16. Sofiya Rusova: Z malovidomoho i nevidomoho. - Chastyna 1. "Nestorka ukrayins'koyi pedahohichnoyi literatury..." / Uporyadnyky O. Dzhus, 3. Nahachevs'ka. - Ivano-Frankivs'k : Hostynets', 2006. - 456 s.

17. Frumkyn K.H. Passyonarnost' : pryklyuchenyya odnoy ydey. - M. : Yzd-vo LKY, 2008. - 224 s.

18. Domań R. Tańce, pląsy i zabawy przy muzyce dla dzieci w wieku przedszkolnym / Robert Domań, Iwona Biśto, Jolanta Kaszyca. - Lublin : Wyd. Przedszkolak, 2003. -44 s.

19. Kruglanski A.W. Lay epistemic theory: The motivational, cognitive, and social aspects of knowledge formation // Article in Social and Personality Psychology Compass/ - Blackwell publishing Ltd, October. 2010. - pp. 939-950.

20. Hahn K. Reform mit Augenmaß. Ausgewählte Schriften eines Politikers und Pädagogen / von Michael Knoll ; Kurt Hahn. - Verlag Klett-Cotta, Stuttgart, 1998. - P. 15-29.

21. Heckmair B. Erleben und Lernen. Einführung in die Erlebnispädagogik. 6. Auflage / Bernd Heckmair, Werner Michl. - Verlag E. Reinhardt, München, 2008.

22. Pedagogika zabawy w edukacji kulturalnej: pod. red. Elżbiety KędziorNiczyporuk. - Lublin : Wydawnictwo KLANZA, 2006. - 242 s. 